\title{
Fremmede lande er en fejltagelse
}

\section{Af Matt Qvortrup}

Brexit sagaen ruller videre og kan ende i selvforskyldt økonomisk katastrofe - men historien om briternes mistro over for Europa har en lang historie. Den nuværende krise er resultatet af denne historie og af en splittet britisk folkesjæl, hvor den ene halvdel er skeptisk over for alt udenlandsk, og den anden nærer mistro over for de gamle institutioner.

"Ils sont fous ces anglais" - 'De er skøre de englændere' - smågrinte min franske kollega Laurence med et velvalgt citat af den galliske tegneseriefigur Asterix. Hendes konstatering rummede en del ærlig forvirring, en skefuld forargelse og den knivspids af skadefryd, som borgere i nabolandet hensiddes Kanalen sjældent helt kan skjule over for briterne.

Jeg havde, for Gud ved hvilken gang, gennemgået de tragikomiske trakasserier, som Brexit udsatte os for. Min franske kollega var på besøg med et hold studerende. Hun var - ligesom hendes yngre medrejsende fra Lille forvirret og fandt det 'incroyable', at de britiske politikere tilsyneladende var villige til at lade landet sejle mod den økonomiske afgrund, som nationalbankdirektør Mark Carney havde advaret imod kun nogle få dage tidligere.

Historien er velkendt. Premierminister Theresa May havde faet en aftale med EU. Den betød, i meget korte træk, at briterne ville fortsætte medlemskabet indtil 2021, at London overtog kontrollen med fiskeri og indvandring, men at man i en overgangsperiode ville acceptere de regler (forordninger og direktiver), som EU udstedte. Men, mere kontroversielt, hvis man ikke efterfølgende fik en handelsaftale, ville Nordirland forblive en del af EU's indre marked.

Og så var fanden løs, om ikke i Laksegade så i den britiske pendant, i Liverpool Street. 


\section{Mytteristemning}

Mays støtteparti The Democratic Unionist Party (et parti der har blandet pietistisk og konservativ kristendom med benhård britisk nationalisme) erklærede, at de ikke ville stemme for aftalen. Og Brexitminister Dominic Raab forlod regeringen i protest mod den aftale, han - paradoksalt nok selv havde forhandlet.

Det stod hurtigt klart, at et meget stort flertal af de konservative parlamentsmedlemmer ville stemme imod aftalen, fordi den ikke gik langt nok. Samtidigt erklærede oppositionspartierne - og frem for alt Labour - at de heller ikke kunne støtte den.

Labour var splittet, men ikke så meget som de konservative. Førstnævnte parti havde indgået en borgfred, der betød, at man først ville kræve nyvalg, og hvis der ikke var flertal herfor, kræve en folkeafstemning. Den sidste mulighed var der stigende støtte for. Over 700.000 - primært midaldrende funktionærer - demonstrerede for en ny afstemning. Dette krav blev støttet af flere fremtrædende konservative, blandt andre den tidligere justitsminister Dominic Grieve - en af de få konservative tilhængere af EU.

Theresa May afviste at forhandle med sine backbenchers og fastholdt, at hun ville vinde en afstemning i House of Commons i december. Hun afviste også, at der kunne forhandles om en bedre aftale - og var lodret imod en anden folkeafstemning. En sådan afstemning ville, hævdede hun, 'undergrave tilliden til demokratiet'.

Det var hendes position indtil 10 . december 2018. Præcist atten timer og fjorten minutter inden afstemningen i parlamentet skulle finde sted, foretog regeringen en kovending og udsatte afstemningen til januar - mindre end to måneder inden Storbritannien formelt skulle forlade den Europæiske Union.

Det blev mødt med vrede blandt de knap 100 medlemmer af den konservative parlamentsgruppe, der ikke ønsker en aftale, og som arbejder for en såkaldt Hard Brexit - dvs., at Storbritannien forlader EU uden en aftale og uden at betale de penge, som briterne har forpligtet sig til at betale som en del af det sidste budgetforlig.

Theresa May, som havde gjort meget - for ikke at sige alt - for at tækkes EU-modstanderne, oplevede, at Jacob Rees-Mogg, Dominic Raab og Boris Johnson øjeblikkeligt trak tæppet væk under hende. En af de mere ekstreme, Nadine Dorris, sammenlignede endog Theresa May med Hitler; "Hun sidder i sin bunker og stirrer mod sin egen Untergang, og vi ved, hvordan den historie ender", sagde hun med henvisning til Oliver Hirschbiegels prisbelønnede film om Der Führers sidste dage.

With friends like that, who needs enemies?

Mays modstandere samlede de nødvendige 48 underskrifter, som er nødvendige for at holde en tillidsafstemning. Men de havde gjort regning uden vært. Selvom irritationen med May var - og er - stor, valgte 200 ud af de 317 konservative parlamentsmedlemmer at stemme for May. Hun er dermed fredet $i$ et år. Men det betød ikke, at hun dermed havde fået sin aftale igennem. Der er intet, der 
tyder på, at de konservative rebeller vil stemme for hendes aftale. May fastholder i skrivende stund (18. december), at hun vil genforhandle aftalen med EU. Noget som alle EU's stats- og regeringschefer har afvist.

Nogle har talt om en national samlingsregering, men det er usandsynligt.

Labours leder Jeremy Corbyn er politisk til venstre for Enhedslisten, og det er utænkeligt, at den reformerede trotskist vil gå i regering med 'klassefjenden', når han kan vinde et parlamentsvalg og få indfriet sin ungdoms socialistiske dagdriverdrømme.

\section{Stædig og stivnakket}

At der er uoverstigelige problemer forbundet med den nuværende politiske situation i Storbritannien, skyldes i vid udstrækning konkrete politikere og individer. Og ingen mere end premierministeren.

Theresa May er en særegen og speciel politiker. Hun er lidt selvudslettende, men stædig og stivnakket. Modstandere - og dem har hun mange af - håner hende for ordret at gentage banale almindeligheder, når hun bliver stillet vanskelige spørgsmål.

Det har jeg personligt oplevet. For en snes år siden, da jeg havde udgivet en lille bog om demokratiets krise (Supply-Side Politics), holdt jeg en række oplæg med Theresa May. Jeg skulle tale om krisen, og hun - den etablerede politiker - skulle sige det modsatte.

Hun var høflig og venlig. Men hun lyttede ikke til argumenter. Data, statistikker og uafviselige fakta blev besvaret med et mantra om, at ' $\mathrm{i}$ min valgkreds er der ikke mistro til politikerne. Mine vælgere siger til mig, at der ikke er krise'. Når jeg igen forsøgte at citere undersøgelser, fik jeg bogstavelig talt - nøjagtigt det ordret samme svar: 'I min valgkreds...' Det irriterede tilhørerne, men det tog Mrs May med ophøjet ro.

Med en sammenligning fra litteraturhistorien er Theresa May en Wilkins Micawberfigur; Charles Dickens' fiktive biperson (i romanen David Copperfield) har et evigt refræn, som han konstant gentager, når han - igen og igen undervurderer verdens udfordringer; 'Something will turn up'. Ikke at Micawber var en optimist, der så lyst på livet. Det var han ikke. Men fordi han stivnakket og ærekært nægtede at indrømme, at hans økonomiske beslutninger har bragt ham i ulykke.

\section{Not English}

Dette er ikke det eneste eksempel på hvordan litteraturen - og især Dickens - kan kaste lys over nutiden. Denne artikel handler om Brexit, men for at forstå denne historiske krise, kan det være nyttigt at gå 153 år tilbage i tiden. Nærmere bestemt til et afsnit fra en knaldroman fra datiden:

"Mr Podsnaps verden var ikke scerlig stor, hverken geografisk endsige åndeligt. Og selvom hans indkomst udelukkende kom fra oversøisk handel, opfattede han fremmede lande, som en 'fejltagelse'. Og faldt snakken på deres 
Mr Podsnaps skepsis over for alt europæisk - og udenlandsk - er ikke bare et karakteristikon, man finder i romaner fra en svunden fortid, dengang hvor briterne herskede over et verdensimperium.

kulturer og adford, ville han, med en arrogant håndbevoegelse og en hånlig grimasse, sige 'ikke engelsk'."

Ligesom man i Danmark altid kan finde sindbilledet på den typiske dansker i tv-serien Matador, kan man i England - måske på et lidt højere litterært niveau - finde repræsentanter for den britiske folkesjæl i Charles Dickens' romaner. Og ingen er mere præcist portrætteret end just omtalte John Podsnap fra romanen Our Mutual Friend. Bogen var ikke et litterært kunstværk på niveau med The Pickwick Papers, og ikke et så samfundskritisk indlæg som Oliver Twist, men alligevel, rammende, prægnant og med den trademark selvironi, der også kendetegner nutidens standup-komikere i England.

For Mr Podsnaps skepsis over for alt europæisk - og udenlandsk - er ikke bare et karakteristikon, man finder i romaner fra en svunden fortid, dengang hvor briterne herskede over et verdensimperium. Det er den samme indignation og ditto arrogance, man i de sidste mange år har fundet i læserbrevene i smånationalistiske tabloidaviser som The Daily Express, The Daily Mail - og i den mere seriøse, men ikke mindre nationalromantiske The Daily Telegraph.

I en menneskealder har aviser på højre flanke af det politiske spektrum serveret en daglig dosis af - ikke altid sandruelige - historier om EU og al dets væsen og om, hvordan tyskerne (altid dem) planlægger at underlægge det britiske folk. (Det er ikke uden grund, at en af valgplakaterne i folkeafstemningen i 2016 havde budskabet: 'Halt ze German Advance' og et lidet flatterende billede af Angela Merkel)

The Daily Express' grundlægger, den navnkundige Lord Beaverbrooke (William Maxwell Aitken), erklærede, at hans avis ville give læseren den 'daglige dosis af had'. Det solgte aviser i 1930'erne - og siden firserne har dele af den britiske befolkning, i bogstavelig forstand, elsket at hade EU. Det drog medierne nytte af, og gradvist blev afskyen mod Bruxelles en selvopfyldende profeti.

\section{Provinsfænomen}

Men modstanden mod EU var - som vist også i Danmark - et provinsfænomen. Det var mestendels fiskere, landmænd og dem, der bor langt fra metropolerne, som stemte på det højrepopulistiske United Kingdom Independence Party (UKIP), ligesom det er dem i Hvide Sande, Hjørring og Hadsten, der stemmer på Dansk Folkeparti.

Det var provinsboerne, der følte sig glemt, dem der ikke havde draget nytte af globaliseringen og internationaliseringen, dem der - måske ikke uden grund - projicerede al deres vrede på et EU, der var bureaukratisk, og som så i øvrigt var domineret af tyskere, franskmænd og skandinaver.

Podsnap var - og er - en romanfigur, men hans karakteristik passede 
næsten som fod $\mathrm{i}$ hose på den skepsis, man oplever i den småborgerlige del af arbejderklassen; fra de lavtlønnede, der er trætte af politisk korrekte europæere - og deres britiske medsammensvorne.

Men den victorianske romanfigur var ikke enestående. Shakespeare - no less - havde skrevet om det samme i Richard II, 'dette velsignede sted, dette rige, dette England'. Og i 1970'erne var Alf Garnett i BBC's tv-serie Till Death Us do Part et andet eksempel på den småracistiske og ofte selvtilstrækkelige brite, der nærede et næsegrus had til middelklassens og Londons evige fascination af Europa.

Der har altid været en $\varnothing$-mentalitet i England (i mindre grad i Skotland). The Times overskrift 'Tåge i Kanalen: Kontinentet afskåret' er en myte. Avisen trykte aldrig denne historie, men mange citerer ikke-historien med næsten euforisk selvtilstrækkelighed. Denne digression udi i nationallitteraturen forklarer imidlertid ikke, hvorfor oprøret mod alt det 'udenlandske' rettede sig mod EU.

\section{September 1988}

Historien har aldrig én årsag. Der er altid en række faktorer, der bidrager til verdens gang. Men, disse udspringer ofte af begivenheder, der for eftertiden står som pejlemærker for fremtiden. Med risiko for at oversimplificere, begyndte Brexit helt præcist i dagene mellem den 14. og den 20. september 1988.

Indtil den uge havde de konservative været pragmatiske tilhængere af EF (som det hed dengang).
Margaret Thatcher havde været en ivrig fortaler for Det Indre Market, og 'de fire friheder'. De konservative modstandere var excentrikere som Enoch Powell, der havde forladt partiet i midten af 1970'erne, efter han var på det tabende hold i folkeafstemningen om forbliven i EF i 1975.

Labour, derimod, havde været skeptiske over for De Europæiske Fællesskaber. Partiet havde stemt imod medlemskab i 1971, selvom en stor del af parlamentsmedlemmerne havde brudt med partilinjen og stemt med Edward Heaths konservative regering.

Det ændrede sig gradvist i 1980 'erne. Neil Kinnock, der blev leder af partiet efter det katastrofale valgnederlag i 1983, ønskede at ændre dette. Han og TUC (den britiske pendant til LO) inviterede Kommissionens formand, den franske socialist og tidligere finansminister Jacques Delors, til at holde en tale på årskongressen. Den karismatiske franskmand tog de britiske fagforeningsledere med storm. Han skitserede en plan for et 'socialt Europa', et Europa hvor lønmodtagernes rettigheder var en central del.

Margaret Thatcher - den daværende konservative premierminister - blev rasende. En uge senere, den 20. september, holdt hun sin berømte Brügge-tale, hvori hun sagde: "vi har ikke rullet statens grænser tilbage for at se dem genindført af en europæisk superstat”.

Lad mig slå én ting fast, Storbritannien drømmer ikke om at blive isoleret på den yderste rand af Fællesskabet. Vor fremtid er i Europa, som en del af EF. 
Mange drømmer om en utopisk fremtid, om et hvidt England, hvor der drikkes real ale, spilles cricket, og hvor der ikke tales polsk, dansk eller andre irriterende fremmedsprog.

Det er ofte overset, at Delors ikke nævnte ordet 'føderation', og at Margaret Thatcher også sagde: "Lad mig slå én ting fast, Storbritannien drømmer ikke om at blive isoleret på den yderste rand af Fællesskabet. Vor fremtid er i Europa, som en del af EF".

Men trods denne ikke uvæsentlige præcisering blev Thatchers tale startskuddet til den konservative modstand mod EU. Det var med udgangspunkt i hendes bredside mod Unionen, at højreorienterede konservative etablerede The Bruges Group.

Tredive år senere var tonen blevet meget mere skarp og uforsonlig. The Financial Times kunne således cite- re en konservativ politiker for at sige: "Jeg tror ikke, vi bliver fattigere udenfor [EU], men hvis du fortalte mig, at min familie vil spise græs, så vil jeg stadigvæk have stemt for at forlade EU" (Financial Times, 'The Thirty Years' War over Europe', 15. december, 2018).

Det er ikke et synspunkt, man normalt forbinder med den britiske nationalkarakter, endsige med konservatismen. Det Konservative Parti bygger ideologisk på filosoffen og politikeren Edmund Burke's berømte ord: "Det er med den største forsigtighed, man nedbryder institutioner, der til en rimelig grad har tjent samfundet i flere generationer".

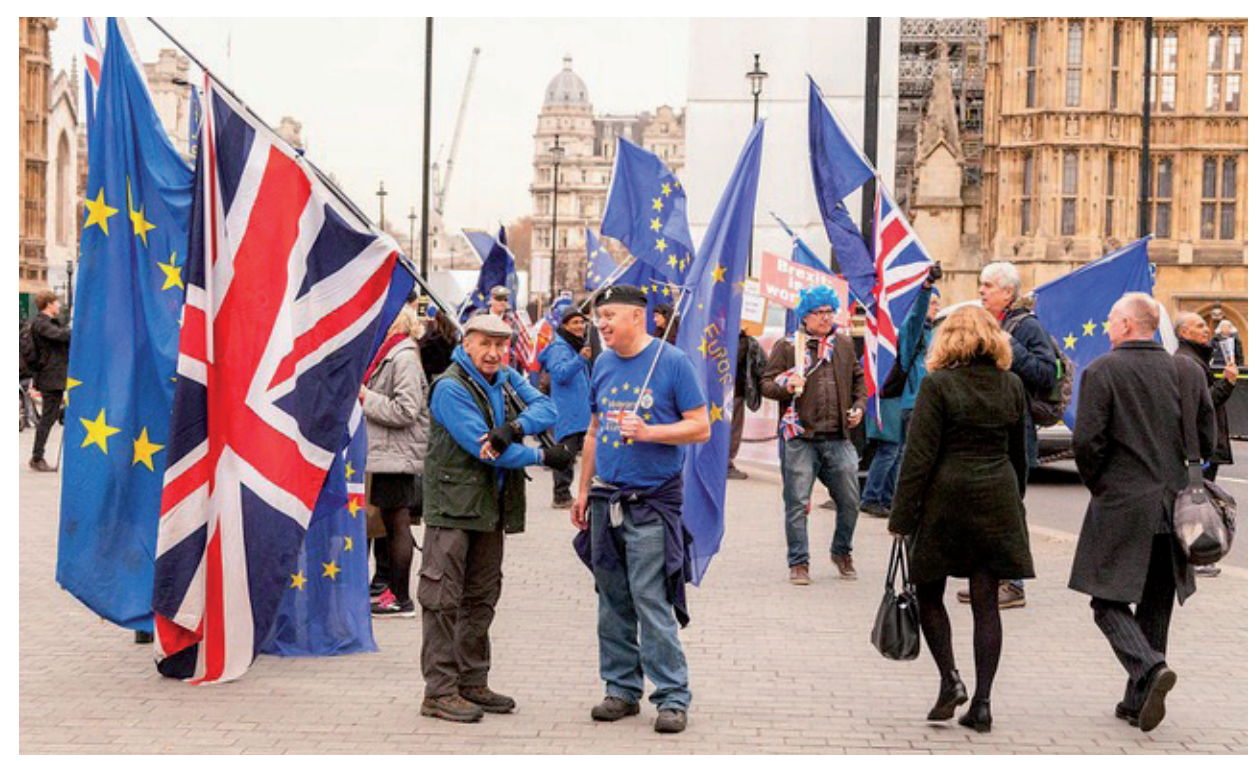

FOTO: Mark Ramsay via Wikimedia Commons

Demonstration mod Brexit, London den 4. december 2018 


\section{Et hvidt England}

Oprøret mod EU gjorde de konservative - især dem i partiforeningerne uden for de store byer - til revolutionære. Mange drømmer om en utopisk fremtid, om et hvidt England, hvor der drikkes real ale, spilles cricket, og hvor der ikke tales polsk, dansk eller andre irriterende fremmedsprog.

Det forstod de aldrig rigtigt i London. I hovedstaden er over 30 pct. af udenlandsk herkomst (herunder denne skribent), der tales 200 forskellige sprog, og borgmesteren er muslim og søn af en buschauffør fra Bangladesh.

Da David Cameron udskrev folkeafstemningen om medlemskab af EU, havde han ingen indfølt forståelse for de følelser, der rørte sig i folkedybet. Jovist, Cameron kunne spille med på en abstrakt modvilje mod Bruxelles-bureaukraterne, men han forstod aldrig rigtigt, hvorfor folk i Sunderland, Grimsby og Wrexham havde en sådan aversion imod EU.

Alt dette betyder selvsagt ikke, at alle briter er varianter af Mr Podsnap. Men at en stor del af dem, der stemte for Brexit, delte romanfigurens opfattelser, er evident. Og at Jacob ReesMogg, formanden for hardlinerne i det konservative parti, bevidst - og lettere affekteret - går klædt som en victoriansk gentleman, understreger blot sammenligningen.

\section{EU-tilhængerne}

Men det er ikke kun til højre i britisk politik, at man kan finde eksempler fra litteraturhistorien, der præcist rammer ned i nutidens politiske personager. På sæt og vis er EU-til- hængerne ligeså karikerede som modstanderne.

George Orwell, forfatteren til 1984 og Kammerat Napoleon, skrev i slutningen af 1940'erne en satire over den herskende klasse, de intellektuelle og venstrefløjen. For disse, skrev Orwell i The Lion and the Unicorn, "er der altid noget skamfuldt forbundet ved at vore engloender, og for dem er der noesten en pligt til altid at fnise hånligt over alle britiske institutioner fra hestevoddeløb til budding".

Grunden til, at Brexit i den grad har splittet den britiske befolkning er, at Orwells beskrivelse af de 'de intellektuelle' har et gran af sandhed i sig, 70 år efter den blev nedfældet; en usagt opfattelse af at det britiske politiske system og dets institutioner er langt underlegne i forhold til Skandinavien, Holland og Tyskland. At denne underlegenhed ofte bliver fremsagt af nogle af verdens mest talentfulde kunstnere, sportsfolk og videnskabsfolk - folk som skuespillerne Idris Elba og Daniel Craig, fodboldspillerne David Beckham og Gary Lineker og den afdøde fysiker Stephen William Hawking - er tankevækkende.

Det er fordi denne opfattelse er så dybt rodfæstnet blandt dem, der læser The Guardian (en avis der svarer til Politiken), at anti-Brexit blev samlingspunkt for de liberale, dem på venstrefløjen og dem, der er skeptiske over for det, de opfatter som stivnede og anakronistiske institutioner som Overhuset, monarkiet og minderne om den glorværdige fortid.

Dem, der drikker cappuccino, læser belgiske tegneserier, ser Borgen på Net- 
Men ligesom højrefløjens euroskeptics projicerede al deres had på Bruxelles, har intellektuelle og de liberale med modsat fortegn kastet al deres kærlighed på en organisation, der primært beskæftiger sig med tekniske handelsspørgmål og monopollovgivning. delse med, endsige noerer nogen sympati for hinanden. To nationer, som er uvidende om hinandens tanker, fø- flix og lytter til Avicii og anden svensk musik, har ikke traditionelt været optaget af - endsige tilhængere af - EU.

Men ligesom højrefløjens euroskeptics projicerede al deres had på Bruxelles, har intellektuelle og de liberale med modsat fortegn kastet al deres kærlighed på en organisation, der primært beskæftiger sig med tekniske handelsspørgmål og monopollovgivning og harmonisering af alt fra tamponer til tyresæd.

Et andet karakteristisk træk var ifølge Orwell, at de intellektuelle sjældent var involverede i praktisk politik. De konservative havde (næsten) monopol på magten, og deres modstandere på venstrefløjen bidrog - og bidrager - kun til en håndfuld liberale tidsskrifter som The New Statesman og Prospect Magazine.

At Labour ikke er kommet med et konkret alternativ til Mays plan, tyder på, at Orwell havde ret, da han i ovennævnte skrift begræd de intellektuelles "konstant negative og kværulantiske attitude og deres totale mangel på konkrete løsnings-forslag".

\section{Aldrig United}

Storbritannien har aldrig været et egentligt United Kingdom. Allerede i 1830 beskrev den senere premierminister Benjamin Disraeli i romanen Sybil England som et land, hvor der er "To nationer, som ikke har nogen forbin- lelser og vaner". Det er stadig korrekt, og det er næppe muligt at slå bro over denne kløft.

Det mest sandsynlige - i skrivende stund - er, at der bliver udskrevet en ny folkeafstemning. Theresa May vil være imod. Kort før jul vedtog Underhuset et beslutningsforslag fremsat af Dominic Grieve, der sikrede, at parlamentet får det sidste ord. Det betyder, med en til vished grænsende sandsynlighed, at parlamentsmedlemmerne vil stoppe en 'hård brexit' (noget, der vil følge med automatik, hvis Parlamentet ikke griber ind eller stemmer for Mays plan). Denne folkeafstemning - hvis den kommer - vil blive hård.

Mange vil med en vis ret sige, at briterne allerede har stemt, og at en anden afstemning er udemokratisk. Andre vil, måske med ligeså god ret, sige, at man nu har konkrete fakta på bordet, og at man, i modsætning til i 2016, ved, hvad det vil koste at stå uden for EU. Dengang var afstemningen abstrakt. Nu er det tal på bordet.

Undersøgelser viser, at mange brugte afstemningen som en anledning til at udtrykke protest mod regeringen og kun i mindre grad som et oprør mod EU. Hvem, der vil vinde en eventuel afstemning, er et åbent spørgsmål.

Det vil blive tæt løb. Meningsmålingerne giver 'Remain' et flertal på tre til fem procent. Men der var ifølge meningsmålingerne et ligeså sikkert for- 
Storbritannien var landet, der - måske sammen med Holland - opfandt det representative demokrati, ideen om lighed for loven og den frie presse. Disse tanker og institutioner lever videre $\mathrm{i}$ andre europæiske lande, men har trange kår i deres fædreland.

spring for Cameron og hans fløj dagen før afstemningen for snart tre år siden.

Det konservative parti, skrev filosoffen John Stuart Mill, har altid været 'det mest ubegavede parti'; et parti der oftest var bagstræberisk, opportunistisk og principløst. Den liberale Mill var ikke noget sandhedsvidne og the stupidest party var - det glemte han at sige - altid gode til at holde fast ved magten. Men meget har ændret sig.

Det hæderkronede parti, der har siddet ved magten i mere end 70 ud af de sidste 100 år, var engang en pragmatisk politisk organisation, der havde et afslappet forhold til ideologi og en deraf følgende evne at vinde valg.

Det var et parti, der altid, og med usvigelig sikkerhed, kunne tage vare på landets økonomiske interesser. Det var middelstandens, industriens og de selvstændige erhvervsdrivendes parti. Det er ikke længere entydigt tilfældet. Det er sigende, at Boris Johnson - der drømmer om at lede partiet - nyligt sagde 'fuck business' - da han i en tale replicerede til erhvervsledere, der havde advaret mod et Hard Brexit.

Engang var det anderledes. Napoleon Bonaparte sagde, at 'England er en nation af småhandlende'. For mange englændere - og især konservative vælgere - blev den franske kejsers nedladende bemærkning om nabolandet til et adelsmærke. For dem var det positivt at 'L'Angleterre est une nation de boutiquiers'.
Boris Johnsons udtalelse siger meget om, hvor langt yderfløjen af det konservative parti har flyttet sig væk fra de gamle idealer. Den britiske ulykke består i, at de Konservative satte partiets succes over den nationale interesse. Det er en fortærsket floskel, at David Cameron kun udskrev folkeafstemningen for at mindske risikoen for at tabe stemmer til UKIP. Og det er ligefuldt en triviel banalitet at sige, at Theresa Mays eneste fokus i forhandlingerne har været at holde sammen på et dybt splittet parti - til trods for hendes besværgelser om 'den nationale interesse'.

Storbritannien var landet, der - måske sammen med Holland - opfandt det repræsentative demokrati, ideen om lighed for loven og den frie presse. Disse tanker og institutioner lever videre $i$ andre europæiske lande men har trange kår i deres fædreland.

Storbritannien ruller mod afgrundens rand. De ansvarlige for katastrofen er politikerne (af begge farver), der satte snæver partipolitisk interesse over det fælles vel. Det ville ikke have overrasket George Orwell. De britiske politikere, skrev han i The Lion and the Unicorn, "begår ikke forrcederi, er ikke bevidst feje, men de er kendetegnede ved ubegribelig dumhed, ubevidst sabotage, og en usvigelig evne til altid at gøre det forkerte". 